\title{
Pendekatan Struktural dalam Pelajaran Bahasa Arab
}

\author{
Oleh: Munir ${ }^{1}$
}

\begin{abstract}
Abstrak
Asumsi tentang bahasa bermacam-macam, antara lain asumsi yang menganggap bahasa sebagai kebiasaan, ada pula yang menganggap bahasa sebagai suatu sistem komunikasi yang pada dasarnya dilisankan, dan ada lagi yang menganggap bahasa sebagai seperangkat kaidah, norma, dan aturan. Asumsi-asumsi tersebut menimbulkan adanya pendekatan-pendekatan yang berbeda, yakni: (1) Pendekatan yang mendasari pendapat bahwa belajar berbahasa, berarti berusaha membiasakan dan menggunakan bahasa untuk berkomunikasi. Tekanannya pada pembiasaan. (2) Pendekatan yang mendasari pendapat bahwa belajar berbahasa, berarti berusaha untuk memperoleh kemampuan berkomunikasi secara lisan. Tekanan pembelajarannya pada pemerolehan kemampuan berbicara. (3) Pendekatan yang mendasari pendapat bahwa dalam pembelajaran bahasa, yang harus diutamakan ialah pemahaman akan kaidah-kaidah yang mendasari ujaran, tekanan pembelajaran pada aspek kognitif bahasa, bukan pada kemampuan menggunakan bahasa. Di antara pendekatan bahasa Arab adalah Pendekatan struktural yang menuntut para pelajarnya untuk memahami rumus-rumus dan istilah-istilah bahasa, dan pelajar diharuskan untuk menghafalkan model-model kalimat atau fungsi kata. Dalam bahasa Arab bisa kita lihat pembelajaran dengan pendekatan struktural dituntut untuk mengetahui fi'il, faa'il, maf'ul dan masih banyak istilah-istilah ilmu bahasa yang lain.
\end{abstract}

Kata Kunci : Bahasa Arab-Pendekatan-Struktural

\section{PENDAHULUAN}

\section{A. Latar Belakang Masalah}

Sebelum al-Qur'an turun, bahasa Arab merupakan bahasa yang tangguh, baik kosa kata, struktur kalimat maupun makna kata-katanya. Bahasa Arab mengandung unsur-unsur yang hidup, keindahan kata kata, dan kesuburan makna yang mampu memikat semua orang sehingga lahirlah karya dalam berbagai ragam ungkapan seperti; puisi, pidato, percakapan, kata-kata hikmah, dan pribahasa. ${ }^{1}$ Dengan datangnya islam dan turunnya al-Qur'an dalam bahasa Arab, kedudukan bahasa Arab menjadi lebih penting dan menarik perhatian dari kalangan masyarakat yang lebih luas.

Di sinilah salah satu keagungan al-Qur'an yaitu menyatukan seluruh dialek sekaligus menjadikan bahasa arab versi al-Qur'an sebagai pemersatu di antara bangsa yang menggunakan Bahasa Arab. Dengan demikian al-Qur'an meletakkan tatanan kaidah gramatika, morfologi, fonetik,semantik, dan unsur kesusastraan yang tinggi. ${ }^{2}$

Dari segi pedagogik pembelajaran bahasa telah melahirkan banyak teori pendekatan, metode, strategi, teknik, model, dan media pembelajaran baik yang merupakan adopsi dari ilmu mengajar dan ilmu-ilmu lain yang didesain khusus untuk pendekatan pembelajaran bahasa Arab.

\footnotetext{
${ }^{1}$ Sabaruddin Garancang, Kelas Kata dalam Bahasa Arab (Cet. I; Makassar: Alauddin University Press, 2013), h. 28.

${ }^{2}$ Kamaluddin Abu Nawas, Al-Masā'il al-Lugawiyyah fī al-Qur'ān al-Karīm: Studi Kritis atas Berbagai Persoalan Kebahasaan (Cet.I; Makassar: Alauddin University Press, 2012), h. 19-20
} 
Banyak guru bahasa arab yang mahir dalam berbahasa arab tetapi kurang menguasai kelas dan kurang mampu menciptakan suasana kelas yang aktif dan kreatif. Untuk meningkatkan kualitas pembelajaran bahasa arab, guru harus mempunyai pendekatan, metode, dan teknik tertentu. Penguasaan pengelolaan ini yang disebut kompotensi pedagogik. Guru perlu menciptakan suasana kelas yang aktif dan kreatif.

Merefleksi hal tersebut, salah satu pendekatan yang dapat diterapkan dalam pembelajaran bahasa arab adalah pendekatan struktural yang akan dipaparkan dalam makalah ini.

\section{B. Rumusan Masalah}

Berdasarkan latar belakang tersebut perlu kiranya merumuskan masalah sebagai pijakan untuk terfokusnya kajian makalah ini. Adapun rumusan masalahnya sebagai berikut.

1. Bagaimana pengertian pendekatan struktural dalam pembelajaran Bahasa arab ?

2. Apa cakupan pendekatan struktural dalam pembelajaran Bahasa Arab ?

\section{PEMBAHASAN}

\section{A. Pengertian Pendekatan Struktural Dalam Pembelajaran Bahasa Arab}

Pendekatan Struktural merupakan salah satu pendekatan dalam pembelajaran bahasa yang dilandasi oleh asumsi yang menganggap bahasa sebagai kaidah. Atas dasar anggapan tersebut timbul pemikiran bahwa pembelajaran bahasa harus mengutamakan penguasaan kaidah-kaidah bahasa atau tata bahasa. Oleh sebab itu, pembelajaran bahasa perlu dititik beratkan pada pengetahuan tentang struktur bahasa yang tercakup dalam fonologi, morfologi, dan sintaksis. Dalam hal ini pengetahuan tentang pola-pola kalimat, pola kata, dan suku kata menjadi sangat penting. Dengan struktural, siswa akan menjadi cermat dalam menyusun kalimat, karena mereka memahami kaidah-kaidahnya.

Pendekatan struktural menuntut para pelajarnya untuk memahami rumus-rumus dan istilah-istilah bahasa, dan pelajar diharuskan untuk menghafalkan model-model kalimat atau fungsi kata. Dalam bahasa Arab bisa kita lihat pembelajaran dengan pendekatan struktural dituntut untuk mengetahui fi'il, faa'il, maf'ul dan masih banyak istilah-istilah ilmu bahasa yang lain. Siswa dapat menghafalkan kaidah - kaidah bahasa dengan baik, namun mereka kurang terampil dalam pemakaian bahasa itu sendiri. Dengan kata lain, siswa menjadi kuat pengetahuan bahasanya. tetapi lemah dalam kemampuan berbahasanya.

Tes bahasa dalam kedudukannya memiliki kaitan yang amat erat dengan komponenkomponen lain dalam penyelenggaraan pembelajaran bahasa, terutama komponen pembelajaran yang mendasarinya yaitu kegiatan pembelajaran. Hal serupa berlaku pula pada tujuan pembelajaran untuk menyelenggarankan pembelajaran dengan seluruh rangkaian kegiatan pembelajaran untuk mengetahui tingkat keberhasilan dilakukan evaluasi atau tes bahasa dengan melihat keempat kemampuan bahasa. ${ }^{3}$

\footnotetext{
${ }^{3}$ http://arerariena.wordpress.com/2011/02/02/tes-bahasa/, diakses 15-12-2017
} 
Secara umum pendekatan terhadap bahasa yang akan menentukan dan mendasari dalam menyelenggarakan pendekatan pembelajaran bahasa. Pendekatan pembelajaran bahasa menentukan pendekatan dalam menyelenggarakan tes bahasa berdasarkan keempat kemampuan bahasa.

\section{B. Cakupan Pendekatan Struktural Pembelajaran Bahasa Arab}

Dalam Pendidikan bahasa umumnya ada 3 kaidah yang harus dikuasai siswa tidak terkecuali bahasa arab, yang tercakup dalam Fonologi, morfologi, dan sintaksis.

\section{a. Fonologi}

Bidang linguistik yang mempelajari, menganalisis, dan membicarakan runtutan bunyibunyi bahasa disebut fonologi, yang secara etimologi terbentuk dari kata fon yaitu bunyi dan logi yaitu ilmu. ${ }^{4}$

\section{Fonem}

Fonem adalah kesatuan bunyi yang terkecil dan sistem bunyi-bunyi bahasa yang dapat berfungsi sebagai pembeda makna. Dan fonem juga adalah merupakan objek kajian dalam ilmu fonemik.

\section{Identifikasi Fonem}

Untuk mengetahui apakah sebuah bunyi fonem atau bukan, kita harus mencari sebuah satuan bahasa biasanya sebuah kata, yang mengandung bunyi, lalu membandingkannya dengan satuan kata yang lain yang mirip dengan satuan bahasa yang pertama. kalau ternyata kedua satuan bahasa itu mempunyai makna yang berbeda maka dapat kita simpulkan bahwasanya bunyi tersebut adalah fonem, karena dia bisa atau berfungsi membedakan makna kedua satuan bahasa tersebut. Misalnya, dalam bahasa Indonesia, kata "tajam" dengan "talam". Keduanya memiliki kemiripan bunyi bahkan jumlah bunyinya sama (lima bunyi). "Ternyata perbedaannya hanya pada bunyi " $J$ " dan " $l$ ". Maka dengan demikian,dapat disimpulkan bahwa bunyi " $j$ " dan " $l$ " dalam bahasa Indonesia adalah fonem, karena berfungsi dalam membedakan makna. Dalam bahasa arab juga ditemukan adanya fonem, misalnya pada kata "ذنوب " لزنوب " yang mempunyai arti yang berbeda yaitu "dosa-dosa" dan "bulu ketiak".

\section{Klasifikasi Fonem}

Dalam kajian fonologi, fonem dapat diklasifikasikan atas dua bagian, yaitu : fonem segmental dan fonem suprasegmental. Adapun yang dimaksud dengan fonem segmental adalah vokal dan konsonan dalam fonologi ataupun fonem-fonem yang berupa bunyi yang didapat sebagai hasil segmentasi terhadap arus ujaran. Dan yang dimaksud dengan suprasegmental adalah jalinan atau susunan bunyi yang dapat membedakan arti suatu kata dengan kata yang lain. Sedangkan yang dimaksud dengan segmen adalah satuan bahasa yang diabstraksikan dari suatu teks, misalnya fon atau fonem sebagai suatu bunyi, morf atau morfem sebagai satuan gramatikal.

\footnotetext{
${ }^{4}$ Abdul Chaer, Linguistik Umum, Jakarta, 2012, hlm. 102
} 
4. Identifikasi Fonem Bahasa Arab Berdasarkan Klasifikasi Fonemnya

\section{1) Fonem Vokal}

Dalam pembuktian bunyi-bunyi vokal dalam bahasa arab termasuk fonem atau tidak, dapat dilihat sebagai berikut :

a. Vokal /i/ dan /î/ misal :

$$
\begin{array}{ll}
\text { سن / sinnun/ } & \text { "umum atau gigi" } \\
\text { سين /sîn/ } & \text { "huruf s" }
\end{array}
$$

Vokal /i/ dan /I/ dalam bahasa arab adalah dua buah fonem yang hampir sama namun dapat membedakan makna.

b. Vokal /a/ dan /â/ misal :

$$
\begin{aligned}
& \text { نصر /nasara/ “dia telah menolong” } \\
& \text { ناصر /nâsara/ “saling menolong” }
\end{aligned}
$$

Vokal /a/ dan /â/ dalam bahasa arab adalah dua buah fonem yang hampir sama namun dapat membedakan makna.

c. $\quad$ Vokal $/ \mathrm{u} /$ dan $/ \hat{\mathrm{u}} /$ misalnya :

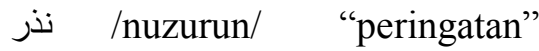

$$
\begin{aligned}
& \text { لذور /nuzûrun/ "nazar” }
\end{aligned}
$$

Vokal /u/ dan / $\mathrm{u} /$ dalam bahasa arab adalah dua buah fonem yang hamper sama, namun dapat membedakan makna.

d. Vokal /i/ dan/a/ misalnya :

$$
\begin{aligned}
& \text { من / } / \mathrm{min} / \text { "dari" } \\
& \text { من /man/ "siapa" }
\end{aligned}
$$

Vokal /i/ dan /a/ dalam bahasa arab adalah dua buah fonem yang hampir sama, namun dapat membedakan makna.

e. Vokal /i/ dan /u/ misalnya :

$$
\begin{array}{ll}
\text { ب /birrun/ "kebaikan" } & \text { "gandum" }
\end{array}
$$


Vokal /i/ dan /u/ dalam bahasa arab adalah dua buah fonem yang hampir sama, namun dapat membedakan makna.

f. vokal /a/ dan $/ \mathrm{u} /$ misalnya :

$$
\begin{aligned}
& \text { / barrun / “daratan" } \\
& \text { بر / burrun / "gandum" }
\end{aligned}
$$

Vokal /a/ dan /u/ dalam bahasa arab adalah dua buah fonem yang hampir sama, namun dapat membedakan makna.

\section{2) Fonem Konsonan}

Diantara beberapa fonem yang teridentifikasi memiliki kesamaan dalam bahasa arab adalah sebagai berikut :

a. $\quad$ konsonan “ت”/t/ dan “b"/t/, misalnya :

$$
\begin{aligned}
& \text { / tin / "buah tin" } \\
& \text { / tin / "tanah" }
\end{aligned}
$$

konsonan "ت"/t/ dan "ط" /t/ dalam bahasa arab adalah dua buah fonem yang berbeda, dan dapat membedakan makna.

b. konsonan “ت"/t/ dan "د"/d/, misalnya ;

$$
\begin{array}{ll}
\text { / tabba / } \quad \text { "celaka, binasa" } \\
\text { تب / dabba / "merangkak, merayap" }
\end{array}
$$

konsonan "ت"/t/ dan "د"/d/ dalam bahasa arab adalah dua buah fonem yang berbeda, dan dapat membedakan makna.

c. konsonan "ك" "ق"/ / / / /, misalnya :

$$
\begin{aligned}
& \text { / kalbun / 'anjing" } \\
& \text { كلب / qalbun / "hati" }
\end{aligned}
$$

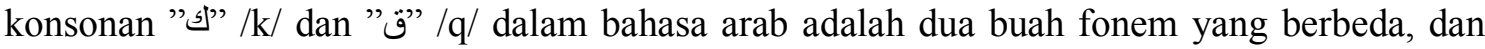
dapat membedakan makna.

d. konsonan "د"/d/ dan "ض"/d/, misalnya : 


$$
\begin{aligned}
& \text { د / dalla / "menunjukkan" } \\
& \text { ض / dalla / "menyesatkan" }
\end{aligned}
$$

e. konsonan "ذ"/z/ dan "b"/z/, misalnya :

$$
\begin{aligned}
& \text { / zalillun / ليل yang hina" } \\
& \text { / zalilun / ليليل }
\end{aligned}
$$

Konsonan "j"/z/ dan "ל" /z/ dalam bahasa arab adalah dua buah fonem yang berbeda, dan dapat membedakan makna.

\section{f. konsonan "w"/s/ dan "ص"/s/, misalnya :}

$$
\begin{array}{ll}
\text { / nasrun / "burung garuda" } \\
\text { نسر / nasrun / “pertolongan" }
\end{array}
$$

Konsonan "w"/s/ dan "ص"/s/ dalam bahasa arab adalah dua buah fonem yang berbeda, dan dapat membedakan makna.

g. konsonan "س”/s/ dan “ش”/sy/, misalnya :

$$
\text { / c c c cmenjaga" }
$$

Konsonan "w"/s/ dan "ش"/sy/ dalam bahasa arab adalah dua buah fonem yang berbeda dan dapat membedakan makna.

h. konsonan “ $\mathrm{"} \mathrm{/h/} \mathrm{dan} \mathrm{"ه"/h/,} \mathrm{misalnya} \mathrm{:}$

$$
\begin{aligned}
& \text { / nahara / "menyembelih" } \\
& \text { ذهر / nahara / "membentak" }
\end{aligned}
$$

Konsonan " $ح$ ”/h/ dan “»" /h/ dalam bahasa arab adalah dua buah fonem yang berbeda dan dapat membedakan makna.

i. konsonan " $ح$ "/h/ dan "ع"/'a/, misalnya :

$$
\begin{aligned}
& \text { / nahlun / "lebah" } \\
& \text { نحل / na'lun / "sendal" }
\end{aligned}
$$

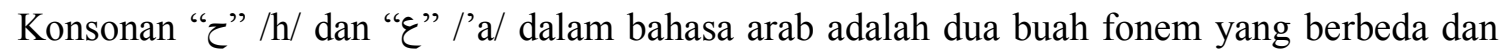
dapat membedakan makna. 
j. konsonan “ø”/'a/ dan “\$”/h/, misalnya :

$$
\begin{aligned}
& \text { / sa'ala / "bertanya" } \\
& \text { سأل / sahala / mudah" }
\end{aligned}
$$

Konsonan “ø”/'a/ dan " " " /h/ dalam bahasa arab adalah dua buah fonem yang berbeda dan dapat membedakan makna.

k. Konsonan “є”/'a/ dan “ع"/'a/, misalnya :

$$
\begin{aligned}
& \text { / badaa / "memulai" } \\
& \text { بدأ / bada'a / "menciptakan" }
\end{aligned}
$$

Konsonan "£"/'a/ dan " $\varepsilon " / / a /$ dalam bahasa arab adalah dua buah fonem yang berbeda dan dapat membedakan makna.

1. konsonan “"ك"/k/ dan “خ”/kh/, misalnya :

$$
\begin{aligned}
& \text { / akbarun / “lebih besar” } \\
& \text { أكبر / akhbarun / “mengabarkan” }
\end{aligned}
$$

Konsonan “ك" / / / dan “ $خ$ ”/ /kh/ dalam bahasa arab adalah dua buah fonem yang berbeda dan dapat membedakan makna.

m. konsonan “ $\dot{\tau}$ ”/kh/ dan “غ்"/g/, misalnya :

$$
\begin{aligned}
& \text { / bikhairin / “dengan baik" } \\
& \text { / bigairin / “dengan yang lain" }
\end{aligned}
$$

Konsonan" $\dot{\tau}$ "/kh/ dan “ $\dot{\varepsilon}$ "/g/ dalam bahasa arab adalah dua buah fonem yang berbeda dan dapat membedakan makna.

n. konsonan “ث”/t/ dan “w”/s/, misalnya :

$$
\begin{aligned}
& \text { / latsama / "mencium" } \\
& \text { لثم / lasama / "mengecap" }
\end{aligned}
$$

Konsonan " $\dot{\tau}$ ”/kh/ dan “غ்"/g/ dalam bahasa arab adalah dua buah fonem yang berbeda dan dapat membedakan makna.

o. konsonan “ j”/z/ dan "ج”/j/, misalnya :

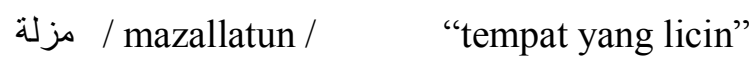




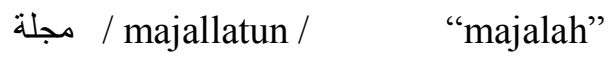

Konsonan “ $j$ " /z/ dan " $ج " / j /$ dalam bahasa arab adalah dua buah fonem yang berbeda dan dapat membedakan makna.

\section{B. Morfologi}

\section{Pengertian Morfologi}

Morfologi adalah bagian linguistik yang mempelajari morfem. Morfologi mempelajari dan menganalisis struktur, bentuk, klasifikasi kata-kata. Dalam pembahasan mengenai fonologi, fonem adalah kesatuan bunyi terkecil yang membedakan arti, seperti pada pasangan mata-mati, kedua bunyi /a/ dan /i/ adalah dua fonem yang membedakan arti.

Menurut al-Ghalayayni (1987: 9) 'ilm al-sharf adalah ilmu yang membahas dasardasar pembentukan kata, termasuk di dalamnya imbuhan. Sharaf memberikan aturan pemakaian masing-masing kata dari segi bentuknya yang dikenal dengan Morfologi. Dengan kata lain bahwa sharaf memberikan aturan pemakaian dan pembentukan kata-kata sebelum digabung atau dirangkai dengan kata-kata yang lain.

Bahasa Arab adalah bahasa yang pola pembentukan katanya sangat beragam dan fleksibel, baik melalui cara derivasi (tashrif isytiqaqy) maupun dengan cara infleksi (tashrif i'raby). Dengan dua cara tersebut, bahasa Arab menjadi sangat kaya dengan kosakata.

Bahasa Arab dari segi pengembangan makna gramatikal ditandai dengan Isytiqaq, yang menjadikan kata-kata Arab berubah secara elastis dalam kata itu sendiri. Dari satu kata عَلَّم umpamanya, dapat dikembangkan menjadi jumlah kata sepertia pada kolom dibawah ini.

\begin{tabular}{|c|c|c|c|}
\hline الاندونيسية & العربية & الاندونبيسة & العربية \\
\hline Tahu, mengetahui & عَلِ & Tahu, pengetahuan & عِ \\
\hline Mengajar & عَلَّم & Orang pandai & كالم \\
\hline Memberi informasi & 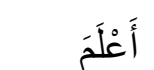 & Maha Mengetahui & ليلح \\
\hline Meminta informasi & اسْتَعْعْلَ & Yang luas ilmunya & 2 \\
\hline Ilmu-ilmu & عُلُوم & Diketaui & \\
\hline
\end{tabular}

Bahasa Arab termasuk bahasa yang infleksi, pengembangan makna gramatikal dilakukan dengan cara mengembangkan satu bentuk menjadi sejumlah bentuk untuk menunjukan variasi makna yang berbeda. Lain halnya dalam bahasa Indonesia dan bahasa Inggris, yang dalam pengembangan makna gramatikalnya banyak mengandalkan proses afiksasi (awalan, akhiran, sisipan), dan reduplikasi (pengulangan), seperti pada tabel di atas. 
Dari perbandingan itu tampak bahasa Arab lebih ajeg (qiyasi) dalam pemahaman makna, dan lebih simpel bentuk pengembangannya (ijaz), karena perubahan terjadi secara internal, tidak perlu banyak mengandalkan afiksasi atau reduplikasi. ${ }^{5}$

\section{Pokok Pembahasan Morfologi Bahasa Arab (Tashrif al-Ishthilahiy)}

Cakupan yang dibahas dalam morfologi bahasa Arab biasanya terkait dengan bentuk dan perubahan bentuk fi 'il madhi, fi'il mudhari, mashdar, isim fa'il, isim maf'ul, isim makan, isim alat, dst.

\section{Contoh Tahsrif al-Ishthilahiy:}

\begin{tabular}{|c|c|c|c|c|c|c|c|c|c|}
\hline سم الالة & المكان & الزمان & فلهل & فعل & المفعول & الفاعل & مصدر & فضل المضارى & الماضعى \\
\hline \multirow[t]{4}{*}{ منصر } & منصر & منصر & لاتنصر & انصر & منصور & ناصر & نصرا & ينصر & نصر \\
\hline & مكرم & مكرم & لاتكرم & اكرم & مكرم & مكرم & اكر اما & يكرم & اكرم \\
\hline & مكتسب & مكتسب & لاتكتسب & اكتسب & مكتسب & مكتسب & اكتشـابا & يكتسب & اكتسب \\
\hline & مستغفر & مستغفر & لاتستخ & استغفر & مستغفر & مستغفر & استغفار ا & يست & است \\
\hline
\end{tabular}

\section{Sintaksis}

\section{Pengertian Sintaksis}

Kata sintaksis berasal dari kata Yunani (sun = 'dengan' + tattein 'menempatkan'. Jadi kata sintaksis secara etimologis berarti menempatkan bersama-sama kata-kata menjadi kelompok kata atau kalimat. ${ }^{6}$ Sintaksis adalah tata bahasa yang membahas hubungan antarkata dalam tuturan.

Pada tahun 1981, Ramlan mengatakan sintaksis adalah bagian atau cabang dari ilmu bahasa yang membicarakan seluk-beluk wacana, kalimat, klausa dan frase. Ramlan mengatakan kalimat adalah satuan aramatik yang dibatasi oleh adanya jeda panjang yang disertai nada akhir turun atau naik. ${ }^{7}$ Sintaksis merupakan salah satu unsur kebahasaan yang sangat komplek setap bahasa memiliki struktur kebahasaan masing-masing. Dengan demikian, struktur masing-masing bshasa akan berbeda. Perbedaan itu antara lain adalah pola struktur fonologi, morpologi dan sintaksis.

Dalam bahasa arab, pengaturan antar kata dalam kalimat atau antar kaliamat dalam klausa atau wacana merupakan kajian ilmu Nahwu. Bahkan hubungan itu tidak hanya

5 Prof. Dr. H. Aziz Fachrurrozi, MA dan Erta Mahyudin, Lc., S.S., M.Pd.I., Teknik Pembelajaran Bahasa Arab, Lembaga Bahasa Yassarna YBMQ Jakarta, hlm. 17-18

${ }^{6}$ Dr. Mansoer Pateda, Linguistik Sebuah Pengantar, Bandung, 2011, hal. 97

${ }^{7}$ Dr. Mansoer Pateda, hal. 85 
menimbulkan makna gramatikal, tetapi juga mempengaruhi baris akhir masing-masinga kata yang kemudian disebut dengan I'rab. ${ }^{8}$

Dalam pembahasan sintaksis yang biasa dibicarakan tataran sintaksis yang mencakup masalah fungsi, kategori, peranan sintaksis. Birbacara tentang tataran sintaksis berarti kita berbicara tentang jabatan-jabatan kata dalam kalimat. Seperti halnya kita sering mendengar istilah-istilah Subyek. Prediket, objek, kata sifat, kata benda, kata keterangan, kalimat aktif, kalimat fasif, dan lain-lain. Dalam kaitan ini Verhaar membagi tataran sintaksis kepada tiga yaitu: Fungsi-fungsi sintaksis, Kategori sintaksis, dan Peranan sintaksis.

\section{Fungsi-fungsi Sintaksis}

Fungsi-fungsi sintakasis itu biasanya terdiri dari unsur-unsur S,P,O,K yakni mencakup istilah Subjek, Peredikat,Objek dan Keterangan. Dalam bahasa arab fungsi-fungsi sintaksis kita kenal dengan istilah antara lain :

مفعولفيه, مفعولمعه, مفعول لأجاه ,خبر رمبتد أ,نائبالفاعل,مفعولبه,فاعل

\section{Katagori Sintaksis}

Katagori sebagai tataran di bawah fungsi-fungsi sintaksis. Hal ini mencakup istilah-istilah kata benda (nomina), kata kerja( verba), kata kata sifat( adjektiva), kata depan (numeralia), dll.

Menurut para ahli tatabahasa tradisional berpendapat bahwa fungsi subjek harus di isi oleh kategori nomina, fungsi predikat harus diisi oleh katagori verba, sedangkan fungsi objek harus di isi oleh kategori nomina, dan fungsi keterangan harus selalu diisi oleh kategori adverbia.

Dalam bahasa arab kita mengenal istilah istilah اسم: (nomina), فعل (verba ), (preposisi). Ketiganya disebut jenis-jenis kalimat.

\section{Peranan Sintakasis}

Peran dinilai sebagi tataran terendah dalam sintaksisi. Hal ini mencakup istilah-istilah subjek dan objek atau pelaku dan penderita, penerima, fasif atau aktif dan lain-lain. Dalam bahasa arab sejauh pengamatan kami hal ini tidak ditemukan. ${ }^{9}$

\section{Sintaksis Dalam Bahasa Arab}

Seperti yang telah disinggung sebelumnya, bahwa pengaturan antara kata dalam kalimat, atau antar kalimat dalam klausa atau wacana merupakan kajian ilmu nahwu. Bahkan hubungan itu tidak hanya menimbulkan struktur dan makna gramatikal saja, tetapi juga mempengaruhi bris akhir msing-masing kata yang kemudian dikenal dengan i'rab.

\footnotetext{
${ }^{8}$ Sahkholid, Pengantar Linguistik: analisis teori-teori linguistik umum dalam bahasa arab)(Nara Press, Medan, 2006), h. 124

9. Sahkholid, Pengantar Linguistik, h 125
} 


\section{Fungsi-Fungsi Sintaksis Bahasa Arab.}

Sebagaimana disebutkan sebelumnya bahwa fungsi sintaksis disibut juga dengan jabatan atau fungsi kata dalam kalimat. Dalam bahasa arab, jabatan atau fungsi kata itu diklasifikasikan sesuai dengan jenis i'rabnya. Adapun fungsi-fungsi sintaksis dalam bahasa arab sesuai dengan jenis i'rabnya.

Kategori sintaksis bahasa arab dibagi kepada tiga, yaitu isim(nomina), fi'il(verba), dan huruf (preposisi). Ketiganya disebut dengan اقسامالكلمة jenis-jenis kalimat.

Dapat dipastikan, bahwa semua fungsi sintaksis bahasa arab diatas adalah berkategori isim. Namun demikian, sering juga ditemukan yang berkategori fi'il, tetapi hal ini sudah berbentuk jumlah.

Hubungan sintaksis bahasa arab melahirkan apa yang dikenal dengan jumlah. Dan jumlah ini dapat dibagi kepada dua:

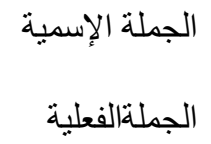

Sementara itu, ada juga yang disebut dengan semi jumlah atau شبهالجملة secara sederhana, yang dimaksud dengan jumlah ismiah adalah kalamat yang dimulai dengan kata isim. Denga kata lain, kalimat yang terdiri dari mubtada' dan khabar.

Sebaliknya,yang dimaksud dengan jumlah fi'liah ialah setiap kalimat yanga di mulai dengan kata Fi'il atau dengan kata lain setiap kalimat yang tersusun deri Fi'il dan Fa'il. Sementara syibhul jumlah adalah kalimat yang tersusun dari jar + majrurr dan dzhorof + mudhafun ila'ih. Jadi dapat dipastikan bahwa hal yang pokok dalam sebuah kalimat bahasa arab adalah Mubtada' dan Fi'il. Sementara itu kalau ada mubtada' pasti ada khabar, demikian juga pada Fi'il, juka fi' 'ilnya ada maka pasti terdapat $\mathrm{Fa}^{\prime}$ 'il. ${ }^{10}$

\section{KESIMPULAN}

1. Pendekatan Struktural merupakan salah satu pendekatan dalam pembelajaran bahasa yang dilandasi oleh asumsi yang menganggap bahasa sebagai kaidah. Atas dasar anggapan tersebut timbul pemikiran bahwa pembelajaran bahasa harus mengutamakan penguasaan kaidah-kaidah bahasa atau tata bahasa. Pendekatan struktural menuntut para pelajarnya untuk memahami rumus-rumus dan istilah-istilah bahasa, dan pelajar diharuskan untuk menghafalkan model-model kalimat atau fungsi kata.

2. Pendidikan bahasa umumnya ada 3 kaidah yang harus dikuasai siswa tidak terkecuali bahasa arab, yang tercakup dalam Fonologi, morfologi, dan sintaksis

a. Fonologi : Bidang linguistik yang mempelajari, menganalisis, dan membicarakan runtutan bunyi-bunyi bahasa disebut fonologi, yang secara etimologi terbentuk dari kata fon yaitu bunyi dan logi yaitu ilmu.

\footnotetext{
${ }^{10}$ Sahkholid, Pengantar Linguistik, h 134
} 
b. Morfologi adalah bagian linguistik yang mempelajari morfem. Morfologi mempelajari dan menganalisis struktur, bentuk, klasifikasi kata-kata.

c. Sintaksis adalah bagian atau cabang dari ilmu bahasa yang membicarakan selukbeluk wacana, kalimat, klausa dan frase. Ramlan mengatakan kalimat adalah satuan aramatik yang dibatasi oleh adanya jeda panjang yang disertai nada akhir turun atau naik.

\section{DAFTAR PUSTAKA}

Chaer, Abdul. Linguistik Umum. Jakarta. 2012.

Fachrurrozi, Aziz \& Erta Mahyuddin. Teknik Pembelajaran Bahasa Arab. Lembaga Bahasa Yassarna YBMQ: Jakarta, t.th.

Pateda, Dr. Mansoer. Linguistik Sebuah Pengantar. Bandung, 2011.

Tawīlah, Abd. Wahab Abd. Salām. Al-Tarbiyah al-Islāmiyyah wa Fan al-Tadrīs. Kairo: Dār al-Salām. 2003.

Sahkholid, Pengantar Linguistik: analisis teori-teori linguistik umum dalam bahasa arab. Nara Press. Medan. 2006.

http://arerariena.wordpress.com/2011/02/02/tes-bahasa/, diakses 15-12-2017. 